\title{
DETECTION OF ESCHERICHIA COLI USING PCR ANALYSIS WITHOUT DNA EXTRACTION
}

\author{
Wimbuh Tri Widodo ${ }^{1}$, Choirul Huda ${ }^{2}$ \\ ${ }^{1}$ Department of Health Analyst, STIKES Karya Putra Bangsa, Tulungagung, Indonesia \\ ${ }^{2}$ Department of Pharmacy, STIKES Karya Putra Bangsa, Tulungagung, Indonesia
}

\begin{abstract}
This study aimed to detect Escherichia coli directly without DNA extraction. The nucleus membrane and cell membranes of the Escherichia coli are composed of a phospholipid bilayer, damaged if heated at $95^{\circ} C$. Predenaturation and denaturation of PCR were carried out at $95^{\circ} \mathrm{C}$. The two stages are thought to be able to break down the Escherichia coli cells so that the DNA that comes out of the cells can directly become a template in the PCR analysis. In this study, PCR analysis was carried out using Escherichia coli culture, Escherichia coli bacteria culture incubated at $95^{\circ} \mathrm{C}$, and Escherichia coli bacteria cultures incubated at $65^{\circ} \mathrm{C}+$ on ice as templates. The results showed that PCR analysis using Escherichia coli culture directly and Escherichia coli culture incubated at $65^{\circ} \mathrm{C}+$ on ice as templates produced very thin DNA bands with a size of 580 bp. while PCR analysis using Escherichia coli bacteria culture incubated at $95^{\circ} \mathrm{C}$ as a template produced thick DNA bands with a size of 580 bp. This study's results are very useful for saving time and costs in the detection of Escherichia coli bacteria. The sample to be tested does not need DNA isolation as usual, but only needs to be incubated at $95^{\circ} \mathrm{C}$ for 10 minutes.
\end{abstract}

Keywords: escherichia coli, PCR, polymerase chain reaction

\section{ABSTRAK}

Penelitian ini bertujuan untuk deteksi bakteri Escherichia coli secara langsung tanpa ektraksi DNA. Membran inti dan membran sel bakteri Escherichia coli tersusun dari fosfolipid bilayer yang akan rusak jika dipanaskan pada suhu $95^{\circ} \mathrm{C}$. Analisis PCR melewati tahapan predenaturasi dan denaturasi dengan suhu $95^{\circ}$ C. Kedua tahapan tersebut diduga mampu memecah sel bakteri Escherichia coli sehingga DNA yang keluar dari sel dapat langsung menjadi template dalam analis PCR. Dalam penelitian ini dilakukan analisis PCR dengan template biakan bakteri Escherichia coli, biakan bakteri Escherichia coli yang diinkubasi suhu $95^{\circ} \mathrm{C}$ serta biakan bakteri Escherichia coli yang diinkubasi suhu $65^{\circ} \mathrm{C}+$ on ice. Hasil penelitian menunjukkan bahwa analisis PCR dengan template biakan bakteri Escherichia coli secara langsung dan biakan bakteri Escherichia coli yang diinkubasi suhu $65^{\circ} \mathrm{C}+$ on ice menghasilkan pita DNA sangat tipis dengan ukuran 580 bp, sedangkan analisis PCR menggunakan biakan bakteri Escherichia coli yang diinkubasi suhu $95^{\circ} \mathrm{C}$ menghasilkan pita DNA tebal dengan ukuran 580 bp. Hasil penelitian ini sangat bermanfaat untuk menghemat waktu dan biaya dalam deteksi bakteri Escherichia coli. Sampel yang akan diuji tidak perlu diisolasi DNA seperti biasanya, namun hanya perlu diinkubasi pada suhu $95^{\circ} \mathrm{C}$ selama 10 menit.

Kata kunci: escherichia coli; PCR; polimerase chain reaction

Correspondence: Wimbuh Tri Widodo, Department of Health Analyst, STIKES Karya Putra Bangsa, Tulungagung, Indonesia. Email: wimbuhtriwidodo@gmail.com

pISSN:2355-8393 • eISSN: 2599-056x • doi: 10.20473/fmi.v57i2.22097

- Fol Med Indones. 2021;57:147-150 • Received 18 Sept $2020 \bullet$ Accepted 10 Dec 2020

- Open access under CC-BY-NC-SA license • Available at https://e-journal.unair.ac.id/FMI/ 


\section{INTRODUCTION}

Polymerase Chain Reaction (PCR) analysis has been proven having high accuracy and using in various purposes, including for disease diagnosis (Cherpillod et al 2016), forensic (Widodo at al 2018), genetic engineering (Bernardi et al 2019) and others. Before the PCR analysis, DNA must be separated from cells through DNA extraction. In general, the DNA extraction procedure goes through three stages, namely the process of cell lysing, protein removal and DNA purification (Sambrook \& Russell 2001). The time required for DNA extraction is relatively the same, and sometimes even longer than the time required for PCR analysis (Ghatak et al 2013). The price of the reagent used for DNA extraction is higher than the reagent price for PCR analysis.

Escherichia coli has DNA located in the cell nucleus (Reece et al 2010, Verma et al 2019). The nuclear membrane and cell membrane in Escherichia coli are composed of phospholipid bilayers and membrane proteins, both of which will break when heated at $95^{\circ} \mathrm{C}$ (Jackson \& Gradmann 2018). Predenaturation and denaturation in the PCR carried out at $95^{\circ} \mathrm{C}$ are predicted to be able to lyse Escherichia coli cells. The DNA that comes out of the cell can become a template in PCR (Farrar \& Wittwer 2015, Yustinadewi et al 2018), so that the detection of Escherichia coli can be done without DNA extraction as usual.

In this study, PCR analysis was carried out using direct culture of Escherichia coli, cultures of Escherichia coli incubated at $95^{\circ} \mathrm{C}$, and cultures of Escherichia coli incubated $65^{\circ} \mathrm{C}$ as templates without DNA isolation as usual.

The results of this study are expected to find a method for the detection of Escherichia coli without carrying out the DNA extraction steps to shorten the time and save costs in the detection of Escherichia coli.

\section{MATERIALS AND METHODS}

This study used a pair of primers using forward sequences: GGG AGT AAA GTT AAT ACC TTT GCT $\mathrm{C}$ and reverse sequences: TTC CCG AAG GCA CAT TCT amplifying genes encoding ribosomal RNA (rRNA) with a length of $580 \mathrm{bp}$.

One of Escherichia coli colony inoculated in LB media and incubated for 24 hours then the DNA was isolated using the Genomic DNA Purification Wizard (Promega) (El-Ashram et al 2016). Isolated DNA was used as a control.
Escherichia coli culture in LB medium was incubated for 24 hours, then (a) used directly as a template for PCR analysis; (b) $10 \mu \mathrm{L}$ was taken and mixed with 90 $\mu \mathrm{l}$ of TE buffer then incubated at $98^{\circ} \mathrm{C}$ for 10 minutes. It was centrifuged at $8000 \mathrm{rpm}$ for 10 minutes. The supernatant resulting from centrifugation was used as a template for PCR analysis; (c) $10 \mu \mathrm{L}$ was taken and mixed with $90 \mu \mathrm{l}$ of TE buffer then incubated at $65^{\circ} \mathrm{C}$ for 10 minutes, followed by incubation in ice for 5 minutes. It was centrifuged at $8000 \mathrm{rpm}$ for 10 minutes. The supernatant from centrifugation was used as a template for PCR analysis.

Each of $1 \mu \mathrm{l}$ of the template (DNA and Escherichia coli) was mixed with $2.5 \mu \mathrm{l}$ of forward primer, $2.5 \mu \mathrm{l}$ of reverse primer, $12.5 \mu \mathrm{l}$ of GoTaq ${ }^{\circledR}$ Green Master Mix Promega, and $6.5 \mu \mathrm{l}$ ddH2O. The mixture was homogenized and run PCR with predenaturation steps at $95^{\circ} \mathrm{C}$ for 2 minutes, denaturation at $95^{\circ} \mathrm{C}$ for 60 seconds, annealing at $57^{\circ} \mathrm{C}$ for 30 seconds, elongation at $72^{\circ} \mathrm{C}$ for 50 seconds, and post-elongation at $72^{\circ} \mathrm{C}$ for 5 minutes. PCR analysis was performed with 40 cycles. The PCR results were electrophoresed in $2 \%$ agarose gel.

\section{RESULTS}

The results of PCR analysis using DNA templates isolated from Escherichia coli incubated in LB media for 24 hours showed a DNA band with a length of 580 bp (Figure 1).

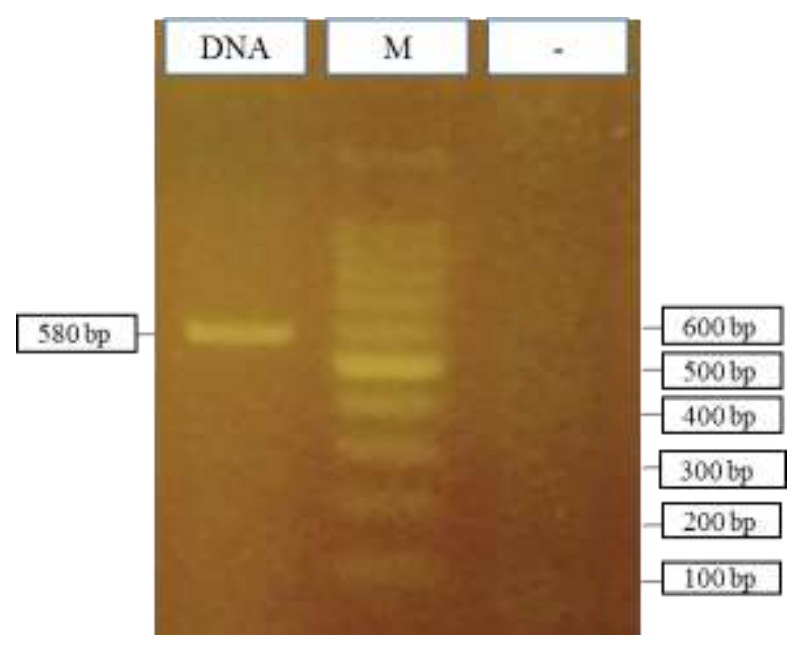

Figure 1. Visualization of PCR results in $2 \%$ agarose gel using DNA of Escherichia coli as a template; DNA: using DNA of Escherichia coli as a template; $\mathrm{M}=\mathrm{DNA}$ Marker; - = negative control. 
The PCR analysis results using Escherichia coli incubated in LB media for 24 hours directly as a template showed very thin DNA bands (Figure 2).

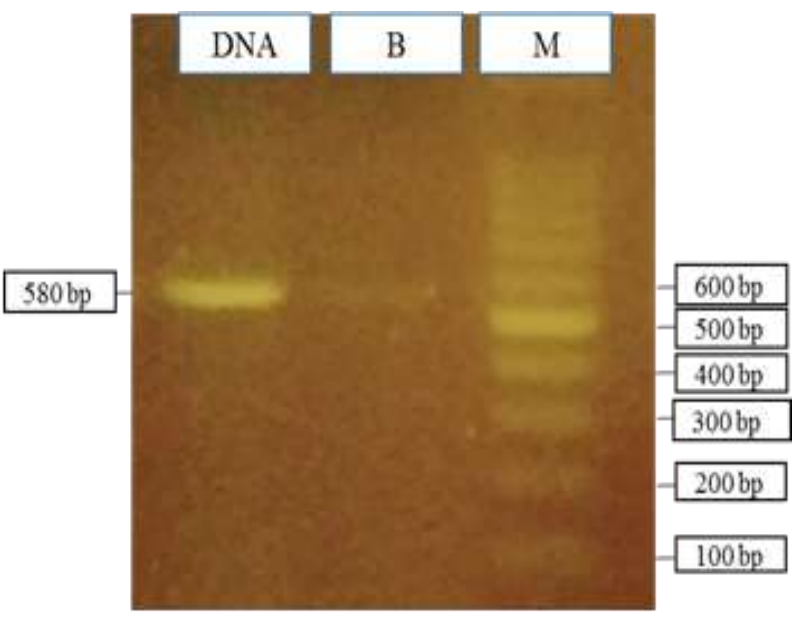

Figure 2. Visualization of PCR results in agarose $2 \%$ using Escherichia coli culture as template; DNA: using DNA of Escherichia coli as a template, B: using Escherichia coli culture as template, M: Marker

PCR analysis was using Escherichia coli cultures that had been incubated at $95^{\circ} \mathrm{C}$ for 10 minutes as a template produces thick DNA bands (580 bp) while PCR analysis using Escherichia coli cultures that had been incubated at $65^{\circ} \mathrm{C}$ then incubated in ice for 5 minutes as a template produces thin DNA bands (580 bp) (Figure 3).

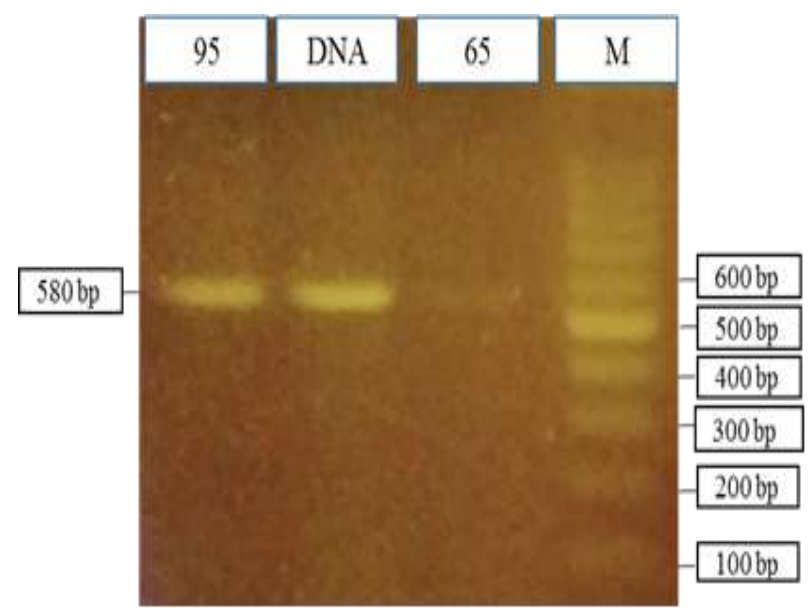

Figure 3. Visualization of PCR analysis results in agarose $2 \%$ using incubated Escherichia coli cultures at $95^{\circ} \mathrm{C}$ and $65^{\circ} \mathrm{C}$ as templates; (95) were incubated at $95^{\circ} \mathrm{C}$ for 10 minutes, $(65)$ were incubated at $650 \mathrm{C}$ then incubated in ice for 5 minutes, $\mathrm{M}=$ marker

\section{DISCUSSION}

The reverse and forward primers used in this study could amplify Escherichia coli DNA fragments in the $16 \mathrm{~S}$ RNA coding gene. It was proven by forming a DNA band with a length of 580 bp when PCR analysis used DNA of Escherichia coli as template. These results were the same as those Tsen et al (1998) who performed PCR with the same primers.

The use of Escherichia coli as a template directly and the incubation treatment of $65^{\circ} \mathrm{C}+$ on ice was not yet adequate for cell lyses. Almost all of the DNA was still in the cell, so that the resulting DNA bands were highly thin. The thinness of the DNA bands was due to highly few DNA templates (Lorenz 2012, Setiati et al 2019). In contrast, the incubation treatment of $95^{\circ} \mathrm{C}$ for 10 minutes in the Escherichia coli culture was proven to be effective in breaking the phospholipid bilayer on the nuclear membranes and cell membranes. Due to the rupture of both membranes, the cell would undergo lysis, and the DNA would come out of the cell, so that it would be amplified when used as a DNA template. This was proven by the formation of thick DNA bands in the PCR using Escherichia coli cultures incubated at $95^{\circ} \mathrm{C}$ for 10 minutes as template. The thickness of the DNA band was due to the number of available DNA templates. The more template DNA, the thicker the DNA band was formed (Wu et al 2010).

The appearance of DNA bands in PCR analysis using Escherichia coli culture incubated at $95^{\circ} \mathrm{C}$ for 10 minutes as a template became a breakthrough in diagnosing bacteria, especially Escherichia coli. The diagnosis of Escherichia coli would be faster and cheaper, because it did not need DNA extraction, such as the usual DNA extraction protocol.

\section{CONCLUSION}

The results of this study were useful for saving time and money in detecting Escherichia coli. The samples did not require DNA isolation as usual, but only needed to be incubated at $95^{\circ} \mathrm{C}$ for 10 minutes.

\section{ACKNOWLEDGMENT}

This research was funded by a young lecturer research grant (PDP) from the Ministry of Research, Technology and Higher Education (KEMENRISTEKDIKTI). 


\section{REFERENCES}

Bernardi B, Kayacan Y, Akan M, et al (2019). Overexpression of rad51 enables pcr-based gene targeting in lager yeast. Microorganisms 7, 1-12.

Cherpillod P, Schibler M, Vieille G, et al (2016). Ebola virus disease diagnosis by real-time RT-PCR: A comparative study of 11 different procedures. Journal of Clinical Virology 77, 9-14.

El-Ashram S, Al Nasr I, Suo X (2016). Nucleic acid protocols: Extraction and optimization. Biotechnology Reports 12, 33-39.

Farrar JS, Wittwer CT (2015). Extreme PCR: Efficient and specific DNA amplification in 15-60 seconds. Clinical Chemistry 61, 145-153.

Ghatak S, Muthukumaran RB, Nachimuthu SK (2013). A simple method of genomic DNA extraction from human samples for PCR-RFLP analysis. J Biomol Tech 24, 224-231.

Jackson M, Gradmann C (2018). Medical bacteriology: The routledge history of disease. Routledge, UK.

Lorenz TC (2012). Polymerase chain reaction: Basic protocol plus troubleshooting and optimization strategies. Journal of Visualized Experiments 63, 1-15.

Reece JB, Lisa AU, Peter VM, et al (2010). Campbell biology. Pearson, London.
Sambrook J, Russell DW (2001). Molecular Cloning: A Laboratory Manual, Third Edition. Cold Spring Harbor Laboratory Press, New York.

Setiati N, Partaya, Hidayah N (2019). The use of two pairs primer for CO1gene amplification on traded stingray at fish auction Tasik Agung Rembang. Journal of Physics: Conference Series 1567, 1-6.

Tsen HY, Lin CK, Chi WR (1998). Development and use of 16S rRNA gene targeted PCR primers for the identification of Escherichia coli cells in water. Journal of Applied Microbiology 85, 554-60.

Verma SC, Qian Z, Adhya SL (2019). Architecture of the Escherichia coli nucleoid. PLoS Genet 15, 1-35.

Widodo WT, Yudianto A, Astuti WSP (2018). Identification of human DNA in mixture of human and chicken blood using PCR with specific primer of cytochrome B gene. Folia Medica Indonesiana 54, 184-188.

Wu JY, Jiang XT, Jiang YX, et al (2010). Effects of polymerase, template dilution and cycle number on PCR based $16 \mathrm{~S}$ rRNA diversity analysis using the deep sequencing method. BMC Microbiology 10, 1-7.

Yustinadewi PD, Yustiantara PS, Narayan I (2018). Teknik perancangan primer untuk sekuen Gen MDR-1 varian 1199 pada sampel buffy coat pasien anak dengan LLA. JURNAL METAMORFOSA V, 105111. 